\title{
MEDICAL CONDITIONS RELATED TO ISCHEMIC AND HAEMORRHAGIC STROKE: A HOSPITAL BASED STUDY
}

\author{
HOSSAIN MM ${ }^{1}$, SARDAR MH², HASAN ATMH ${ }^{3}$, BARI MA ${ }^{4}$, HOSSAIN SZ $^{5}$, NABI G ${ }^{6}$
}

\begin{abstract}
:
Objective: To evaluate the distribution of common medical conditions related to stroke among Bangladeshi patients.

Methods: This is an observational study. It involved 336 stroke patients from different medicine words in Dhaka Medical College Hospital over a period of twelve months. We evaluated some common established medical conditions observed among stroke patients e.g. age, sex, family history, hypertension, diabetes, ischemic heart disease, smoking, obesity, dyslipidaemia, alcoholism, use of oral contraceptive pill, lack of fresh fruit consumption etc. A predesigned check list was used for data collection.

Result: Among the 336 patients, Most of the stroke events occurred after the age of forty (82.3\%) and the ischemic stroke (72\%) being the most common. Other than the non modifiable risk factors (advancing age, sex, Family history of stroke) hypertension was the most common factor found in relation to stroke patients (57.6\%) followed by smoking (44.6\%), tobacco use (24.3\%), OCP use in female (40\% of female stroke), diabetes (23\%), ischemic heart disease (17.1\%), obesity (10.6\%) and dyslipidaemia (5.3\%).

Conclusion: Stroke is common after the age of forty. Ischemic events are commonest type of stroke. Hypertension, smoking, diabetes, tobacco use, and ischemic heart disease were five most common conditions related to stroke.
\end{abstract}

Key words: Stroke, hypertension, diabetes.

J Dhaka Med Coll. 2014; 23(2) : 167-174.

\section{Introduction:}

Stroke is the second leading cause of death worldwide and a major cause of disability among adult in most of the regions ${ }^{1,2}$. About 16.3 million people suffer from stroke worldwide each year, among which 11.2 million events occur in developing countries including Bangladesh. About 5.8 million people die of stroke each year, the two third of which occurs in developing nations ${ }^{2}$. An estimated 64.5 million stroke patients survived an acute stroke event and living with varying degree of disability $^{2}$. Worldwide, stroke consumes about $2-4 \%$ of total health-care costs, and in industrialized countries, stroke accounts for more than $4 \%$ of direct health-care costs ${ }^{3}$.
Though the trend of stroke mortality in developing countries is largely unknown, the average age adjusted mortality of stroke differs even among the developed countries ${ }^{4}$. The geographic variation may be due to difference of risk factor prevalence, genetic susceptibility and level of healthcare facilities. Even though there has been a constant reduction in stroke mortality in developed countries during the past 50 years ${ }^{5}$, it is less certain about trends in developing countries. The most acceptable explanation for the reduction in mortality in western countries is improved control of stroke risk factors (especially high blood pressure and cigarette smoking) combined with a parallel improvement in living standards ${ }^{6-13}$.

1. Dr. Mohammad Murad Hossain, Assistant Professor, Dept of Medicine, Dhaka Medical College, Dhaka.

2. Dr. Md. Hafiz Sardar, Associate Professor, Dept of Medicine, Dhaka Medical College, Dhaka.

3. Dr A.T.M. Hasibul Hasan, Medical Officer, Department of Neurology, Dhaka Medical College Hospital, Dhaka.

4. Dr Mohammad Anwarul Bari,. Assistant Professor, Dept of Medicine, Sir Salimullah Medical College, Dhaka.

5. Dr. Syed Zakir Hossain, Assistant Professor, Department of Medicine, Dhaka Medical College, Dhaka

6. Dr. Golam Nabi, Assistant Professor, Department of Medicine, Z. H. Sikder Women's Medical College, Dhaka Address of Correspondence: Dr Mohammad Murad Hossain, Assistant Professor of Medicine, Dhaka Medical College, Dhaka. Cell Phone: +8801711112984, Email: mhossaink53@gmail.com 
Bangladesh is a small country in South Asia with high density of population (an average of 964 inhabitants/ square kilometer) ${ }^{14}$. The prevalence of stroke here is 3 per 1000 above the age of 40 years ${ }^{15}$. We could find few similar studies involving stroke patients ${ }^{16-18}$. So we conducted the study in medicine ward of Dhaka Medical College Hospital (DMCH), Dhaka, involving a considerable sample to know about the distribution of common factors related to stroke.

\section{Methods:}

This cross sectional study was conducted in medicine wards of Dhaka Medical College Hospital involving 336 patients over a period of one year. The diagnosis of was based on WHO definition of stroke, with the support of convincing history, compatible clinical examination finding and confirmed by CT scan of Head. MRI of brain was done only in required cases eg suspected cerebellar or brain stem stroke. We excluded patients with recurrent stroke, encephalopathy from this study. We collected all the data using a preformed questionnaire. Required information about presence of other factors e.g. age, sex, family history, hypertension, diabetes, ischemic heart disease (IHD), smoking, obesity, dyslipidaemia, alcoholism, use of oral contraceptive pill, pregnancy, Patients were evaluated meticulously with history, clinical examination and necessary investigation at the time of hospital visit by specialists in medicine. All findings were noted and recorded.

\section{Results:}

In this study the majority of strokes occur after the age of 40 years $(82.3 \%)$, the most common being in 51-60 years age group (31.1\%), followed by $41-50$ years age group (27.5\%). Ischemic stroke was common in all age group. Stroke events showed a male preponderance $(73.4 \%)$. The male to female ratio for ischemic stroke was $3: 1$, as compared to $2: 1$ for heamorrhagic stroke. We found that about $6 \%$ of the patients had history of stroke within the family (Table-I). Ischemic stroke was the most frequent event
(72\%), followed by intracerebral hemorrhage $(23 \%)$ and subarchnoid hemorrhage (5\%) (Figure-I). Hypertension was the most common risk factor in stroke patients (56.7\%). Smoking was the next common entity (44.6\%) in stroke patients after hypertension followed by tobacco use $(24.3 \%)$ and Diabetes (23\%). History of ischemic heart disease, in the form of acute coronary syndrome, was present in $17.1 \%$ stroke patients and dyslipidaemia in $5.3 \%$. About $10.6 \%$ patients were obese $(\mathrm{BMI}>24.9)$. A good proportion of female stroke patients $(40 \%)$ took oral contraceptive pills. A very few patients $(1.2 \%)$ were binge alcohol drinker (Figure-II).

Table I

Non modifiable risk factors of stroke $(N=336)$

\begin{tabular}{|c|c|c|c|}
\hline \multicolumn{3}{|l|}{ Parameter } & \multirow{2}{*}{ Percentage } \\
\hline Total & ISH & HRG & \\
\hline \multicolumn{4}{|l|}{$\overline{\text { Age }}$} \\
\hline $11-20 y r$ & 2.3 & 0.7 & 1.6 \\
\hline $21-30 y r$ & 3.1 & 2.4 & 0.6 \\
\hline $31-40 y r$ & 12.3 & 9.6 & 2.6 \\
\hline $41-50 y r$ & 27.5 & 22.4 & 5.1 \\
\hline $51-60 y r$ & 31.1 & 24.1 & 7.0 \\
\hline$>60$ yrs & 23.7 & 18.3 & 5.4 \\
\hline \multicolumn{4}{|l|}{ Sex } \\
\hline Male & 73.4 & 58.1 & 15.3 \\
\hline Female & 26.6 & 18.9 & 7.6 \\
\hline \multicolumn{4}{|c|}{ Family History of Stroke } \\
\hline \multicolumn{3}{|c|}{ Positive family history of stroke } & 6 \\
\hline
\end{tabular}

Table-I shows non modifiable risk factors in stroke patients. Most of the patients are older than 40 years and male.

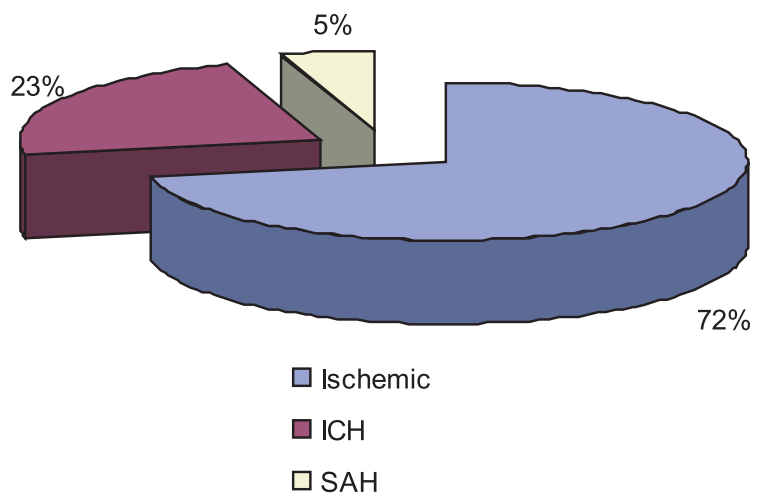

Fig.-1: Distribution of stroke subtype, showing that about $3 / 4^{\text {th }}$ of the patient had ischemic stroke 


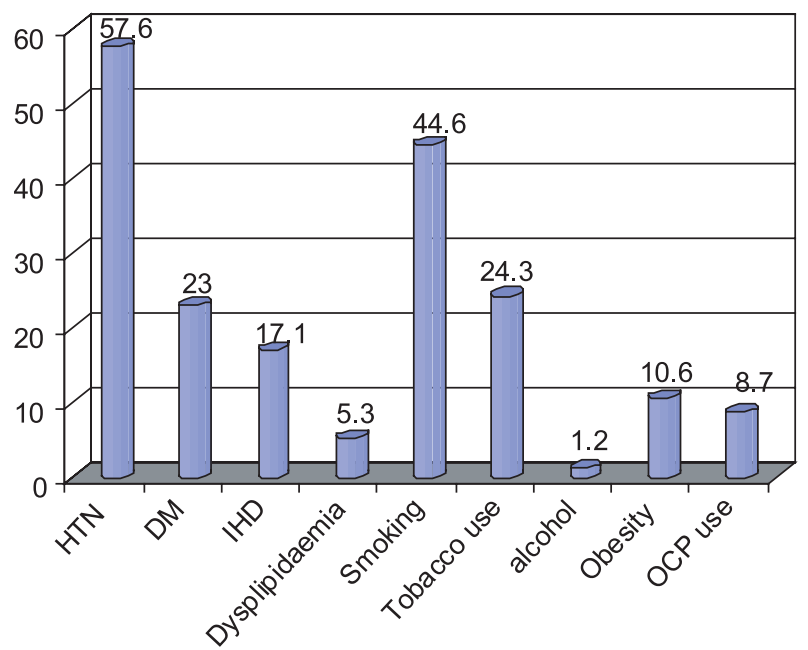

Fig-2: Shows modifiable risk factors of stroke. The most common are HTN, DM, Smoking, IHD, Obesity and Dyslipidaemia.

\section{Discussion:}

Hospital-based stroke registries help to study the relationship between stroke, risk factors and prognosis. The present report provides the detail information regarding stroke subtypes and distribution of common factors and medical conditions related to stroke. Our study provides essential information on common, nonmodifiable and potentially modifiable vascular risk factors, and builds on previous epidemiological studies ${ }^{19-28}$. It is well established that the incidence of stroke rises steeply with age ${ }^{29}$, a finding that is consistent in most of the studies conducted worldwide ${ }^{30-}$ 34. The highest age specific rates occurred in Japan, Russia, and Ukraine ${ }^{31,35,36}$. We also have observed age specific increased frequency of stroke after forty and commonly with ischemic events. But in our study stroke events are common at much younger age (40-60 years) than other parts of the world. The overall difference in life expectancy may be a possible explanation for the fact. Though rare, before the age of 20 years, heamorrhagic events were seen frequently. Chen et $\mathrm{al}^{37}$ also reported a relatively higher incidence of heamorrhagic stroke in children below 10 years and 10-19 years, irrespective of sexes. A recent study from Texas also showed higher incidence of heamorrhagic stroke than ischemic (3.2 versus 1.1 per 10000$)^{38}$. Thus we have confirmed from the observation of previous studies that ischemia is much more common than hemorrhagic events in adulthood stroke ${ }^{39-41}$. But geographic variation exists for childhood stroke. The estimates of the incidence rates for childhood stroke ranged from 2.1 to 13 per 100,000 children-years in Hong-Kong, the United States and France ${ }^{42-44}$. Stroke was three times higher among male in our study, a fact also established by others ${ }^{45}$. The Framingham Heart Study found a higher risk of stroke in men than in women until age 84 years, when risk in women exceeded that in $\mathrm{men}^{46}$. Data from a population-based study from Sweden also showed a reversal in the sex difference with advanced age ${ }^{47}$. Others have reported that stroke risk in men remains higher than that in women throughout life, although the magnitude of the sex difference diminishes with age ${ }^{48,49}$. Still others have reported that the sex differences no longer exist at older ages ${ }^{50-51}$. In the socio economic and cultural context of Bangladesh, female stroke patients are often reluctant to get hospitalized. So not surprisingly we found less number of female stroke patients. Likewise in other developing countries, in our study, ischaemic stroke represents the majority of stroke subtypes, followed by primary intracranial haemorrhage and subarachnoid haemorrhage 52,53 . In developed countries, up to $67.3-80.5 \%$ of strokes are attributed to ischaemic stroke, whereas $6.5-19.6 \%$ are primary intracerebral haemorrhage, about $0.8-7 \%$ are subarachnoid haemorrhage, and $2-14.5 \%$ are of undefined type $^{54}$. In some developing countries, there is a tendency for a higher proportion of haemorrhagic strokes than in western countries. Most of the East Asian studies have suggested that the proportion of intracerebral haemorrhage is significantly higher (up to 35\% of the total) than in people of European descent ${ }^{55}$.

We found the frequencies of the common factors or medical conditions related to stroke in Bangladesh to be similar to those of the other countries ${ }^{56,57}$. Consistent with previous studies $^{21}$, our findings showed that hypertension was the most common risk factor $(57.6 \%)$ for all stroke subtypes. Reports from both the 
developing and developed world are similar in this regard ${ }^{5-61}$. The high frequency of hypertension is probably due to self reporting of patients and the clinic recording of increased blood pressure. Systemic review study also confirms this type of finding ${ }^{62-65}$. Consistent with the report of bak et al ${ }^{66}$ smoking was the next major risk factor of stroke following hypertension in the present study. Daily smoking also doubled the risk of stroke among male in Europe, Honolulu and China 65,67-69. Though smoking is uncommon among Bangladeshi women, they are habituated more to tobacco use in the form of betel nut chewing, which is evident by this study (one fourth of the stroke patient chewed betel nut with tobacco). Ischemic heart disease and ischemic stroke shares common modifiable risk factors. Hence, it is not surprising to find that one in every six stroke patient had associated ischemic heart disease. Our finding is also supported by the report of Jorgensen et $\mathrm{al}^{69}$.

We observed an increased frequency of stroke among diabetic population which is also established by several other studies for the last thirty years. ${ }^{71-74}$ This increase has been connected to the pathophysiological changes seen in the cerebral vessels of patients with diabetes. ${ }^{75,76}$ The relative risk of stroke is approximately doubled compared with that in patients without diabetes ${ }^{77}$. As in ischemic heart disease, obesity and dyslipidaemia were also common as risk factor of stroke in our study. Though truncal fat may be better predictor ${ }^{78}$, most of the epidemiologic studies measured BMI like us. High BMI significantly predicted stroke in several studies ${ }^{79-81}$. Thus, the excess risk was approximately $30 \%$ per BMI unit in Framingham men ${ }^{67}, 10 \%$ in JapaneseAmerican men in Honolulu. The role of hyperlipidaemia on stroke has been studied by several researchers. Statins have been shown to reduce stroke incidence by $29 \%$ in some tirals ${ }^{81-84}$. Haque et al. ${ }^{85}$ also confirmed a strong association of LDL-cholesterol and triglyceride with ischemic stroke among Bangladeshi patients. A considerable fraction of women in our study $(40 \%)$ used oral contraceptives (OCP). OCP increases the risk of cerebral infarction up to 9 fold $^{87}$ and the risk cumulates among women with hypertension, migraine and smoking ${ }^{86-90}$. The relation between alcohol intake and stroke seems complex one. Epidemiological studies confirmed that alcohol intake has a J-shaped relation with ischaemic stroke, but is associated with a graded increased risk of haemorrhagic stroke. Due to social and cultural and legal restrictions in our country, the frequency of drinking alcohol was minimal ${ }^{91}$.

Nonetheless we had some limitations in this study. Though this hospital based observational study may not reflect the real scenario within the community. Moreover, we could not measure the odd ratio for individual risk factors due to the nature of the study. This warrants further case control studies to confirm the level of association.

\section{Conclusion:}

Stroke is common after the age of forty but patients in Bangladesh have stroke at relatively younger age than the west. Similar to other low income countries, our findings suggest that five simple factors or medical conditions are associated with majority of the risk of ischaemic and intracerebral haemorrhagic stroke in Bangladesh. Targeted interventions could substantially reduce the overall burden of stroke.

\section{References:}

1. Feigin VL. Stroke in developing countries: can the epidemic be stopped and outcomes improved? Lancet Neurol 2007; 6: 94-97.

2. Strong K, Mathers C, Bonita R. Preventing stroke: saving lives around the world. Lancet Neurol 2007; 6: 182-7.

3. American Heart Association. Heart and Stroke Facts Statistics: Dallas: American Heart Association, 1997.

4. Bonita R. Epidemiology of stroke. Lancet 1992; 339: 342-44.

5. Bonita R, Beaglehole R. Increased treatment of hypertension does not explain the decline in stroke mortality in the United States, 1970-1980. Hypertension 1989; 13: 169-73.

6. Thrift AG, Dewey HM, Sturm JW, et al. Greater incidence of both fatal and nonfatal strokes in disadvantaged areas: the Northeast Melbourne Stroke Incidence Study. Stroke 2006; 37: 87782. 
7. McQueen MJ, Hawken S, Wang X, et al, for the INTERHEART study investigators. Lipids, lipoproteins, and apolipoproteins as risk markers of myocardial infarction in 52 countries (the INTERHEART study): a case-control study. Lancet 2008; 372: 224-33.

8. Yusuf S, Hawken S, Ounpuu S, et al, on behalf of the INTERHEART Study Investigators. Eff ect of potentially modifi able risk factors associated with myocardial infarction in 52 countries (the INTERHEART study): case-control study. Lancet 2004; 364: 937-52.

9. Rosengren A, Hawken S, Ounpuu S, et al, for the INTERHEART investigators. Association of psychosocial risk factors with risk of acute myocardial infarction in 11119 cases and 13648 controls from 52 countries (the INTERHEART study): case-control study. Lancet 2004; 364: 95362 .

10. Teo KK, Ounpuu S, Hawken S, et al, on behalf of the INTERHEART Study Investigators. Tobacco use and risk of myocardial infarction in 52 countries in the INTERHEART study: a case-control study. Lancet 2006; 368: 647-58.

11. Yusuf S, Hawken S, Ounpuu S, et al, on behalf of the INTERHEART Study Investigators. Obesity and the risk of myocardial infarction in 27000 participants from 52 countries: a case-control study. Lancet 2005; 366: 1640-9.

12. Donnan GA, Fisher M, Macleod M, Davis SM. Stroke. Lancet 2008; 371: 1612-23.

13. Bangladesh Bureau of Statistics. Population and housing census 2011. Preliminary result, July $2011 ;$ p.8.

14. Mohammad QD, Habib M, Hoque A, Alam B et al. Prevalence of stroke above forty years. Mymenshingh Med J 2011; 20(4): 640-4.

15. Hossain MZ, Ahmed SU, Sarder MH et al. Analysis of risk factors associated with stroke in young adults: a prospective study. J Dhaka Med Coll 2009;18(2): 95-100.

16. Siddique MAN, Nur $Z$, Mahbub MS et al. Clinical presentation and epidemiology of stroke: a study of 100 cases. J medicine 2009; 10: 86-9.

17. Hossain AM, Ahmed NU, Rahman M et al. Analysis of sociodemographic and clinical factors associated with hospitalized stroke patients of Bangladesh. Faridpur Med Coll J 2011; 6(1): 1923.

18. Philip A Wolf. Prevention of stroke. Lancet 1998; 352 (suppl III):15-8.

19. Ezzati M, Hoorn SV, Rodgers A, Lopez AD, Mathers CD, Murray CJL, the Comparative Risk Assessment Collaborating Group. Estimates of global and regional potential health gains from reducing multiple major risk factors. Lancet 2003; 362: $271-80$.

20. Lawes CM, Bennett DA, Feigin VL, Rodgers A. Blood pressure and stroke: an overview of published reviews. Stroke 2004; 35: 776-85.

21. Asplund K. What MONICA told us about stroke. Lancet Neurol 2005; 4: 64-68.

22. Johnston SC, Mendis S, Mathers CD. Global variation in stroke burden and mortality: estimates from monitoring, surveillance, and modelling. Lancet Neurol 2009; 8: 345-54.

23. Hankey GJ. Potential new risk factors for ischemic stroke: what is their potential? Stroke 2006; 37: 2181-88.

24. Sacco RL, Khatri M, Rundek T, et al. Improving global vascular risk prediction with behavioral and anthropometric factors. The multiethnic NOMAS (Northern Manhattan Cohort Study). J Am Coll Cardiol 2009; 54: 2303-11.

25. Truelsen $\mathrm{T}$, Mahonen M, Tolonen $\mathrm{H}$, Asplund $\mathrm{K}$, Bonita R, Vanuzzo D. Trends in stroke and coronary heart disease in the WHO MONICA Project. Stroke 2003; 34: 1346-52.

26. Feigin V, Lawes C, Bennet D et al. Worldwide stroke incidence and early case fatality in 56 population based studies: a systematic review. Lancet Neurology 2009; 8 (4): 355-369.

27. Ezzati M, Lopez A, Rodgers A et al. Comparative quantification of health risks. Global and regional burden of disease attritutable to major risk factors. Geneva: WHO 2004.

28. Allen CMC, Lueck CJ, Dennis M. Neurologic disease. In: Colledge NR, Walker BR, Ralston SH, editors. Davidson's Principles and Practice of Medicine. $21^{\text {st }}$ edition. Elsevier Limited; 2010: pp1180 .

29. Jamrozik K, Broadhurst RJ, Lai N, Hankey GJ, Burvill PW, Anderson CS. Trends in the Incidence, severity, and short-term outcome of stroke in Perth, western Australia. Stroke 1999; 30: 2105-11.

30. Morikawa Y, Nakagawa H, Naruse Y, et al. Trends in stroke incidence and acute case fatality in a Japanese rural area: the Oyabe study. Stroke 2000; 31: 1583-7.

31. Kolominsky-Rabas PL, Weber M, Gefeller O, Neundoerfer B, Heuschmann PU. Epidemiology of ischemic stroke subtypes according to TOAST criteria: incidence, recurrence, and long-term survival in ischemic stroke subtypes, a populationbased study. Stroke 2001; 32: 2735-40.

32. Vemmos KN, Bots ML, Tsibouris PK, et al. Stroke incidence and case fatality in southern Greece: the Arcadia stroke registry. Stroke 1999; 30: 363-70. 
33. Smadja D, Cabre P, May F, et al. ERMANCIA: epidemiology of stroke in Martinique, French West Indies, part I: methodology, incidence, and 30day case fatality rate. Stroke 2001; 32: 2741-7.

34. Feigin VL, Wiebers DO, Nikitin YP, O'Fallon WM, Whisnant JP. Stroke epidemiology in Novosibirsk, Russia: a population-based study. Mayo Clin Proc 1995; 70: 847-52.

35. Mihalka L, Smolanka V, Bulecza B, Mulesa S, Bereczki D. A population study of stroke in West Ukraine: incidence, stroke services, and 30-day case fatality. Stroke 2001; 32: 2227-31.

36. Chen PC, Chien KL, Chang CW et al. More Hemorrhagic and Severe Events Cause Higher Hospitalization Care Cost for Childhood Stroke in Taiwan. J Pediatr 2008; 152: 388-93.

37. Zahuranec DB, Brown DL, Lisabeth LD, Morgenstern LB. Is it time for a large, collaborative study of pediatric stroke? Stroke 2005; 36: 1825-9.

38. Hu HH, Sheng WY, Chu FL, Lan CF, Chiang BN. Incidence of stroke in Taiwan. Stroke 1992; 23: 1237-41.

39. Jerntorp P, Berglund G. Stroke registry in Malmo, Sweden. Stroke 1992; 23:357-61.

40. Zhang LF, Yang J, Hong Z, Yuan GG, Zhou BF, Zhao LC, et al. Collaborative Group of China Multicenter Study of Cardiovascular Epidemiology: Proportion of different subtypes of stroke in China. Stroke 2003; 34: 2091-6.

41. Chung B, Wong V. Pediatric stroke among Hong Kong Chinese subjects. Pediatrics 2004; 114: e206-12.

42. Fullerton HJ, Wu YW, Zhao S, Johnston SC. Risk of stroke in children: ethnic and gender disparities. Neurology 2003; 61: 189-94.

43. Giroud M, Lemesle M, Gouyon JB, Nivelon JL, Milan C, Dumas R. Cerebrovascular disease in children under 16 years of age in the city of Dijon, France: a study of incidence and clinical features from 1985 to 1993. J Clin Epidemiol 1995; 48: 1343-8.

44. Kumar P, Clark M, Editors. Kumar \& Clark Clinical Medicine. $7^{\text {th }}$ edition. Spain: Elsevier; 2009 : p.1126.

45. Petrea RE, Beiser AS, Seshadri S, et al. Gender differences in stroke incidence and poststroke disability in the Framingham Heart Study. Stroke. 2009; 40: 1032-7.

46. Lofmark U, Hammarstrom A. Evidence for age dependent education-related differences in men and women with first-ever stroke: results from a community-based incidence study in northern Sweden. Neuroepidemiology. 2007; 28: 135-41.
47. Lewsey JD, Gillies M, Jhund PS, et al. Sex differences in incidence, mortality, and survival in individuals with stroke in Scotland, 1986 to 2005. Stroke. 2009; 40: 1038-43.

48. Hollander M, Koudstaal PJ, Bots ML, et al. Incidence, risk, and case fatality of first ever stroke in the elderly population: the Rotterdam Study. J Neurol Neurosurg Psychiatry. 2003; 74: 317-21.

49. Vega T, Zurriaga O, Ramos JM, et al. Stroke in Spain: epidemiologic incidence and patterns; a health sentinel network study. J Stroke Cerebrovasc Dis. 2009; 18: 11-6.

50. Rothwell PM, Coull AJ, Silver LE, et al. Populationbased study of event-rate, incidence, case fatality, and mortality for all acute vascular events in all arterial territories (Oxford Vascular Study). Lancet. 2005; 366: 1773-83.

51. Oveisgharan S, Sarrafzadegan N, Shirani S, Hosseini S, Hasanzadeh P, Khosravi A. Stroke in Isfahan, Iran: hospital admission and 28-day case fatality rate. Cerebrovasc Dis. 2007; 24(6): 495-9.

52. Ahangar AA, shraf Vaghefi SB, Ramaezani M. Epidemiological evaluation of stroke in Babol, northern Iran (2001-2003) Eur Neurol. 2005; 54(2): 93-7.

53. Feigin VL, Lawes CM, Bennett DA, Anderson CS. Stroke epidemiology: a review of population-based studies of incidence, prevalence, and case-fatality in the late 20th century. Lancet Neurol 2003; 2: 43-53.

54. Sudlow CL, Warlow CP. Comparable studies of the incidence of stroke and its pathological types:results from an international collaboration: International Stroke Incidence Collaboration. Stroke 1997; 28: 491-9.

55. Dyken ML, Wolf PA, Barnett HJM, Beran JJ, Hass WK, Kannel WB, Kuller L, Kurtzke YF, Sundt TM. Risk factors in stroke: a statement for physicians by the subcommittee on risk factors and stroke of the stroke council. Stroke. 1984; 15: 1105-11.

56. Wolf P. An overview of the epidemiology of stroke. Stroke. 1990; 21 (9 Supp1): II-4-II-6.

57. Kumral E, Ozkaya B, Sagduyu A, et al. The Ege Stroke Registry: a hospital-based study in Aegean region, Izmir, Turkey. Cerebrovasc Dis 1998; 8:278-88.

58. Moulin T, Tatu L, Chavot D, et al. Besancom Stroke Registry: an acute stroke registry of 2,500 consecutive patients. Eur Neuro 1997; 38:10-20.

59. McDonnell R, Fan CW, Johnson Z, Crowe M. Prevalence of risk factors for ischaemic stroke and their treatment among a cohort of stroke patients in Dublin. Ir J Med Sci 2000; 169: 253-7. 
60. Kaul S, Venketswamy P, Meena AK, Sahay R, Murthy JM. Frequency, clinical features and risk factors of lacunar infarction (data from a stroke registry in South India). Neurol India 2000; 48(2): 116-9.

61. Ezzati M, Hoorn SV, Rodgers A, Lopez AD, Mathers CD, Murray CJL, the Comparative Risk Assessment Collaborating Group. Estimates of global and regional potential health gains from reducing multiple major risk factors. Lancet 2003; 362: 271-80.

62. The Indian Polycap Study (TIPS). Eff ects of a polypill (Polycap) on risk factors in middle-aged individuals without cardiovascular disease (TIPS): a phase II, double-blind, randomised trial. Lancet 2009; 373: 1341-51.

63. Appel LJ, Anderson CA. Compelling evidence for public health action to reduce salt intake. $\mathrm{N}$ Engl J Med 2010; 362: 650-2.

64. Asplund K, Karvanen J, Giampaoli S et al. Relative Risks for Stroke by Age, Sex, and Population Based on Follow-Up of 18 European Populations in the MORGAM Project. Stroke. 2009; 40: 2319-26.

65. Bak S, Bak L, Sorense JS. Prevalence of risk factors in cerebral ischemia. Ugeskr Laeger 1995; 157: 444-6.

66. Zhang XF, Attia J, D'Este C, Yu XH, Wu XG. A risk score predicted coronary heart disease and stroke in a Chinese cohort. J Clin Epidemiol. 2005; 58: 951-8.

67. Curb JD, Abbott RD, MacLean CJ, Rodriguez BL, Burchfiel CM, Sharp DS, Ross GW, Yano K. Agerelated changes in stroke risk in men with hypertension and normal blood pressure. Stroke. 1996; 27: 819-24.

68. Rodriguez BL, D'Agostino R, Abbott RD, Kagan A, Burchfiel CM, Yano K, Ross GW, Silbershatz H, Higgins MW, Popper J, Wolf PA, Curb JD. Risk of hospitalized stroke in men enrolled in the Honolulu Heart Program and the Framingham study: a comparison of incidence and risk factor effects. Stroke. 2002; 33: 230-6.

69. Jorgensen HS, Nakayama H, Raaschou HO, et al. Intracerebral hemorrhage versus infarction: stroke severity, risk factors and prognosis. Ann Neurol 1995; 38: 45-50.

70. Abbott RD, Donahue RP, MacMahon SW, Reed DM, Yano K. Diabetes and the risk of stroke: the Honolulu Heart Program. JAMA. 1987; 257: 949-52.

71. Davis PH, Dambrosia JM, Schoenberg BS, Shoenberg DG, Pritchard DA, Lilienfeld AM, Whisnant JP. Risk factors for ischemic stroke: a prospective study in Rochester, Minnesota. Ann Neurol. 1987; 22: 319-27.

72. Barrett-Connor E, Khaw KT. Diabetes mellitus: an independent risk factor for stroke? Am J Epidemiol. 1988; 128: 116-23.

73. Boysen G, Nyboe J, Appleyard M, Soelberg Sorensen P, Boas J, Somnier F, Jensen G, Schnohr P. Stroke incidence and risk factors for stroke in Copenhagen. Stroke. 1988; 19: 134553.

74. Alex M, Baron EK, Goldenberg S, Blumenthal HT. An autopsy study of cerebrovascular accident in diabetes mellitus. Circulation. 1962; 25: 663-73.

75. Reske-Nielsen E, Lundback K, Rafaelsen OJ. Pathologic changes in the central and peripheral neurons system of young long term diabetics, I: diabetic encephalopathy. Diabetologia. 1965; 1: 233-41.

76. WHO Study Group on Diabetes Mellitus. World Health Organization Tech Rep Ser 727. Geneva: World Health Organization; 1985.

77. Kragelund C, Omland T. A farewell to body-mass index? Lancet. 2005; 366: 1589-91.

78. Li C, Engstrom G, Hedblad B, Berglund G, Janzon L. Risk factors for stroke in subjects with normal blood pressure: a prospective cohort study. Stroke. 2005; 36: 234-8.

79. Jood K, Jern C, Wilhelmsen L, Rosengren A. Body mass index in mid-life is associated with a first stroke in men: a prospective population study over 28 years. Stroke. 2004; 35: 2764-9.

80. Tanne D, Medalie JH, Goldbourt U. Body fat distribution and long-term risk of stroke mortality. Stroke. 2005; 36: 1021-5.

81. Hebert PR, Gaziano JM, Chan KS, Hennekens $\mathrm{CH}$. Cholesterol lowering with statin drugs, risk of stroke and total mortality: an overview of randomised trials. JAMA 1997; 278: 313-21.

82. Shepherd J, Cobble SM, Ford I, et al. Prevention of coronary artery disease with pravastatin in men with hypercholesterolemia. N Engl J Med 1995; 333: 1301-7.

83. Scandinavian Simvastatin Survival Study Group. Randomised trial of cholesterol lowering in 4444 patients with coronary heart disease: the Scandinavian Simvastatin Survival Study (4S). Lancet 1994; 344: 1383-9.

84. Sack FM, Pfeffer MA, Moye LA, et al, for the Cholesterol and Recurrent Event Trial Investigators. The effect of pravastatin on coronary events after myocardial infarction in patients with average cholesterol levels. N Engl J Med 1996; 335: 1001-9. 
85. Haque AKMF, Islam QT, Rahman KM et al. Serum Lipid as a Risk Factor of Ischaemic Stroke in Bangladeshi People. J MEDICINE 2012; 13: 22-6.

86. Collaborative Group for the Study of Stroke in Young Women: Oral contraception and increased risk of cerebral ischemia or thrombosis. N Engl J Med 1973; 288: 871-8.

87. Collaborative Group for the Study of Stroke in Young Women: Oral contraceptives and stroke in young women, associated risk factors. JAMA 1975; 231: $718-22$.

88. Wiebers DO: Ischemic cerebrovascular complications of pregnancy. Arch Neurol 1985; 42: 1106-13.
89. Fung TT, Rexrode KM, Mantzoros CS, Manson JE, Willett WC, Hu FB. Mediterranean diet and incidence of and mortality from coronary heart disease and stroke in women. Circulation 2009; 119: 1093-100.

90. Iso $\mathrm{H}$, Baba $\mathrm{S}$, Mannami $\mathrm{T}$, et al. Alcohol consumption and risk of stroke among middleaged men: the JPHC Study Cohort I. Stroke 2004; 35: $1124-9$.

91. Reynolds K, Lewis B, Nolen JD, Kinney GL, Sathya B, He J. Alcohol consumption and risk of stroke: a meta-analysis. JAMA 2003; 289: 579-88. 